\title{
ORIGINALS
}

\section{Electron Microscopic Histochemistry of Heavy Metals in Islets of Langerhans of Rabbits}

\author{
Sadayosht Yokoh, Osamu Aoj, Zutken Matsuno and Hideo Yoshida
}

Department of Medicine, Kyoto Prefectural University of Medicine (Director: Professor H. YosHIDA), Kyoto, Japan

Received: July 19, 1968

Summary. The modified sulfide-silvor method was applied to the electron microscopic histochemistry of heavy metals (zinc) in the islet cells from normal rabbits, using glutaraldehyde saturated with hydrogen sulfide as a vital fixative. Zine was distinctly localized at the cores of granules in B cells in various amounts. Secretory granules in A cells sometimes revealed a small amount of zinc, whereas other ultrastructures of both $A$ and $B$ cells did not show any positive reaction. The procedure described in the paper was thought to be useful enough for pursuing not only the localization but also the dynamics of zine in pancreatic islets.

Histochimie microscopique électronique des métaux lourds dans les îlots de Langerhans de lapins

Résumé. La méthode au sulfure d'argent modifiée a été appliquée à l'histochimie microscopique électronique des métaux lourds (zinc) dans les cellules insulaires de lapins normaux on utilisant comme fixateur vital la glutaraldéhyde saturée avec du sulfure d'hydrogène. Le zino a été localisé distinctement dans les centres et les membranes limitant les granules dans les cellules $\mathbf{B}$, en quantité variables. Les granules sécrétoires dans les cellules A contenaient parfois une petite quantité de zinc, tandis que les autres ultrastructures des cellules $A$ et $B$ ne mon- trèrent pas de réaction positive. Le procédé décrit dans cet article a été jugé utile pour rechercher non seulement la localisation du zine mais aussi sa dynamique dans les îlots pancréatiques.

Elektronenmikroskopische Histochemie von Schwermetallen in Langerhans'schen Inseln bei Kaninchen

Die modifizierte Sulfid-Silber Methode wurde für elektronenmikroskopisch-histochemische Untersuchungen des Verhaltens von Schwermetallen (Zink) in den Inselzellen von normalen Kaninchen herangezogen. Zur Vitalfixierung diente mit Schwefelwasserstoff gesättigtes Glutaraldehyd. Zink ließ sich deutlich in verschiedenen Mengen im Zentrum und in den Membranen von B-Zellgranula lokalisieren. Auch in den Granula von A-Zellen fand sich gelegentlich Zink in kleinen Mengen, während die übrigen Ultrastrukturen der A- und B-Zelle keine positive Reaktion zeigten. Das in dieser Arbeit beschriebene Verfahren erscheint nicht nur zur Lokalisierung, sondern auch zur Untersuchung des dynamischen Verhaltens von Zink in den Pankreas-Inseln geeignet.

Key-words: Electronmicroscopic histochemistry, zinc, normal rabbit pancreas, $A$ and $B$ cells.
One of the characteristics of the islets cells of the pancreas is their rich zine content. Improvements $[4$, 6] in specificity of the dithizone method presented by OKaMoto $[8,9]$ have made it possible to study zinc distribution in the islets. The results of the studies demonstrated that it varied between different cell types within islets as well as among species. In the rabbit, fair amounts of zine are found in B cells, aggregated at the capillary borders of the cells, but A cells surrounding the centrally located $B$ cells are almost negative $[8,13]$.

The biological role of zinc in B cells is not clearly determined yet. It has been postulated that a complex of insulin with zinc in B cell granules provides a less soluble storage form of insulin. Mask. [5] suggested that other materials (nitrate, oxalacetate, organic phosphate, cystine, histidine and gluthatione) being produced by the enhancement of sugar metabolism, would remove zinc from the less soluble insulin-zinc complex, and insulin would become more soluble for release.

LogotheтоPoulos $[2,3]$ has stated that zine and insulin are linked as a component of the secretion granules of the B cells. Zine might contribute to whatever intermolecular forces keep the granule package to- gether. On the other hand, however, there is some question about the localization of zine in B cells visualized by the method of dithizone, because of its lack of parallelism with secretory granules by the light microscope $[6,16]$.

It was thought to be necessary to begin with the ultrastructural localization of zine in B cells in order to clarify this problem. Recently there have been a few ultrastructural studies $[10,11,12]$ on zinc in the islet cells using the sulfide-silver method presented by Trux. [14] and by Vorgr [15]. Their descriptions, however, are not adequate.

The present study was undertaken to investigate the localization of zine in the islets of rabbits by the modified sulfide-silver procedure of OTsuks [1] for electron microscopic observation. The light microscopic variety of the sulfide-silver method has been widely used in studies on the role of zinc in pancreatic islet tissue, and the specifity of the method has been well established.

\section{Material and Methods}

Five male rabbits weighing $2.0-2.5 \mathrm{~kg}$ were fasted for $12 \mathrm{~h}$ before the experiment. The rabbits were 
infused with a sufficient amount of saline solution via the femoral vein in order to remove blood from the femoral artery. Then one litre of $3 \%$ glutaraldehyde fixative, adjusted to $7.4 \mathrm{pH}$ by MrLoNIG's buffer [7] saturated with hydrogen sulfide, was infused via the same vein. The pancreas was removed, and islets were microdissected under a stereoscopic microscope (Olympus Model SZ) at a low magnification in the same fixative. After $2 \mathrm{~h}$ fixation in the $\mathrm{H}_{2} \mathrm{~S}$-saturated glutaraldehyde fixative, the microdissected islet tissues were rinsed overnight in Millonig's solution.

Fixed islet tissues were immersed and developed in the Timm's reagent for $30 \mathrm{~min}$ in a dark place. After slightly rinsing in distilled water, the tissues were refixed with $1 \%$ osmium tetroxide solution buffered to $7.4 \mathrm{pH}$ by Mrulonig's solution for $1 \mathrm{~h}$. Timm's reagent [14]
a) $20 \%$ arabia gum
$10 \mathrm{ml}$
b) 1 mol silver nitrate sol
c) hydroquinone
citric acid
dist. water
$2.0 \mathrm{~g}$
$5.0 \mathrm{~g}$
$100 \mathrm{ml}$
$\left.\begin{array}{l}0.1 \mathrm{ml} \\ 2.0 \mathrm{ml}\end{array}\right\}$

Refixed islet tissues were stained with the uranyl acetate solution, dehydrated through a series of graded alcohols and embedded in epon epoxy resin in the usual manner. Sections were cut with a glass knife using a Porter-Blum ultramicrotome MT-I, and examined with Hitachi Electron Microscope HU 11 A without poststaining. Thicker sections were placed on a glass slide and observed by the light microscope after staining with $0.05 \%$ toluidine blue solution. Pancreases from normal rabbits were examined by the light microscope using the Trмm and Vотат paraffin embedding method also.

\section{Results}

The light microscopic findings of tissue treated with the original sulfide-silver procedure of TIMm [14] and VoIGT [15] revealed a distinct positive reaction in the cells considered to be $\mathrm{B}$ cells, but almost none in A cells (Fig. 1).

The thicker sections cut from the epon embedded material, which was pretreated by the modified sulfidesilver method for electron microscopy, were examined by the light microscope after staining with $0.05 \%$ toludine blue. The deep brown positive reaction was observed in the cells presumed to be B cells (Fig. 2).

Ultrastructural examination of the islet cells from normal rabbits has been reported elsewhere [17]. The most remarkable differences between $A$ and $B$ cells are the feature of secretory granules and the presence of perinuclear fibrillar substance in the B cell (Fig. 3). At low magnification, distribution of metal obtained by the modified sulfide-silver procedure was limited to the secretory granules in $\mathrm{B}$ cells, and a positive reaction could not be recognized in the A cell granules (Fig. 4). At higher magnification, metal was distinctly localized in the cores of granules of $B$ cells. The silver granules appeared sometimes droplet-like and sometimes like fine grain. There seemed to be an uneven distribution of the metal in the $B$ cell granules. Almost all the mature granules, however, showed a more or less positive reaction. In some secretory granules, positive reaction was stronger at the periphery of the granule than at the central part. Few limiting membranes of granules of the $B$ cell showed a positive reaction (Figs. 5, 6).

A cell granules sometimes contained a few silver grains at high magnification (Fig. 7).

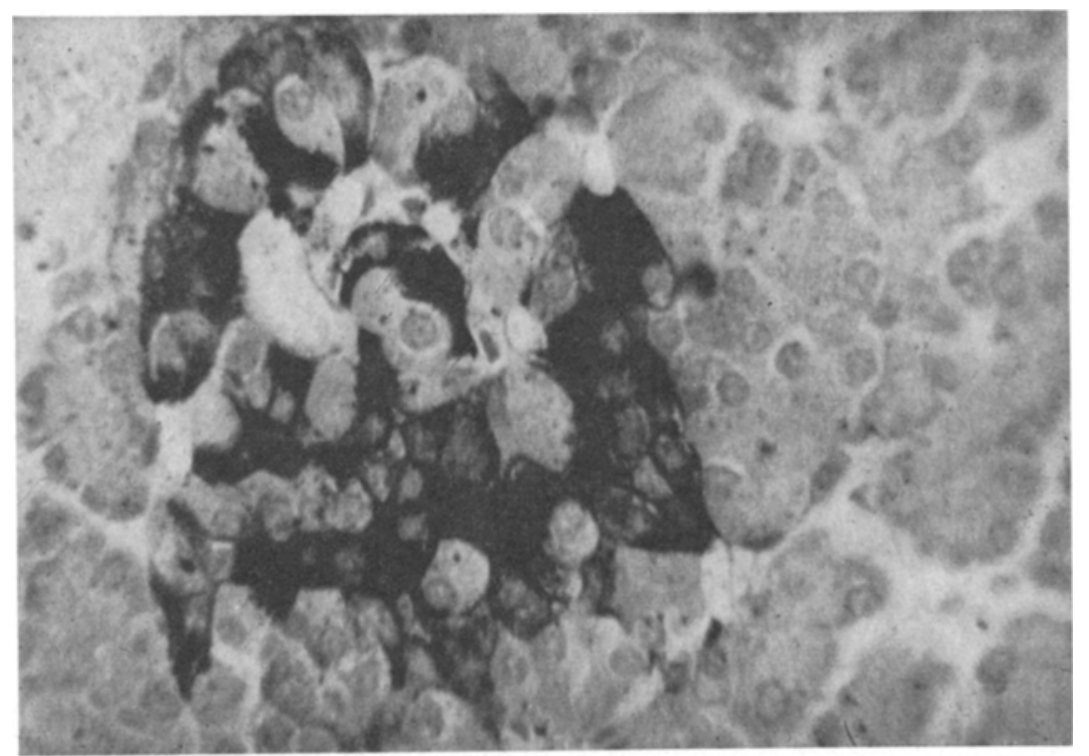

Fig. 1. Pancreatic islet of a normal rabbit. Paraffin-embedded section treated by the sulfide-silver method of Timm. B cells show a positive reaction, but the reaction is negative in A cells. Obj. $\times 40$ and ocul. $\times 10$ 
The physiological role of perinuclear fibrillar substance has not been clear, but this substance did not show any positive reaction. Other intracellular com- ponents, i.e. membrane system of Golgi apparatus, endoplasmic reticulum, and mitochondria also did not react the modified sulfide-silver procedure et all (Fig. 8).

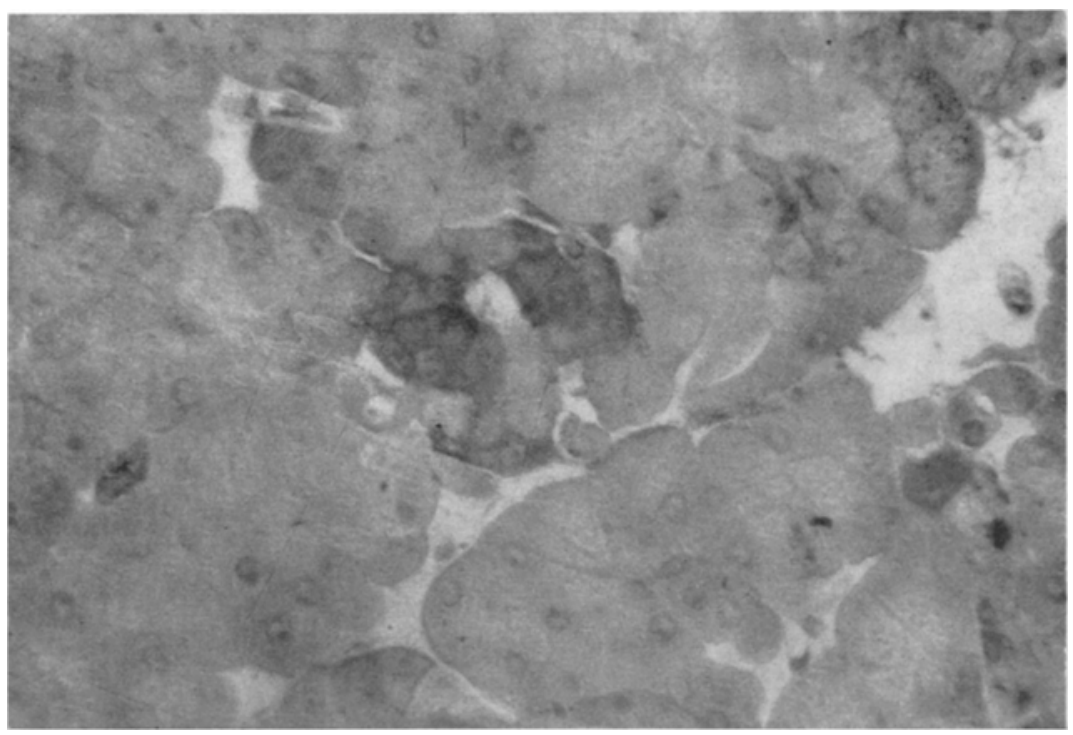

Fig. 2. Thicker section from epon-embedded pancreatic islet tissue after modified sulfide-silver method. Granular precipitate of silver in B cells only. Obj. $\times 40$ and ocul. $\times 10$

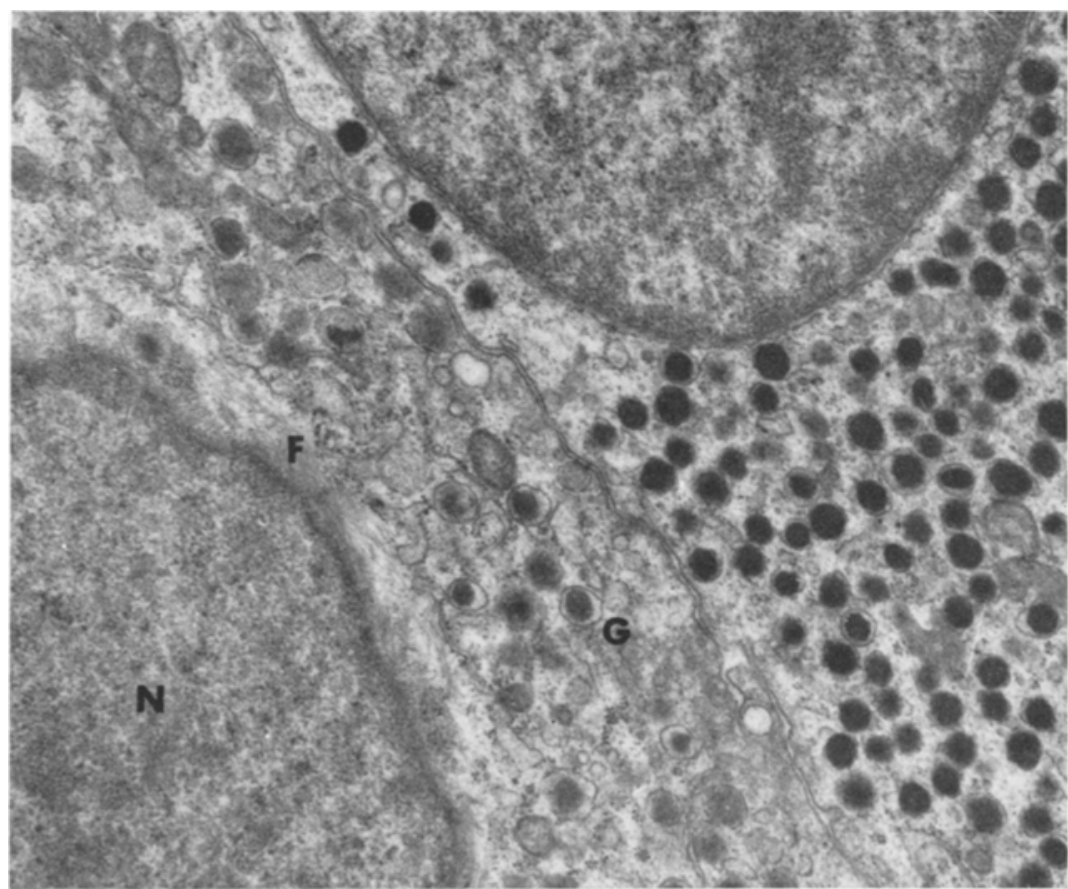

Fig. 3. A (upper right) and B (lower left) cell of a normal rabbit pancreatic islet. $\mathrm{N}$ : nucleus, F : fibrillar substance, G: granule. $\times 16000$ 


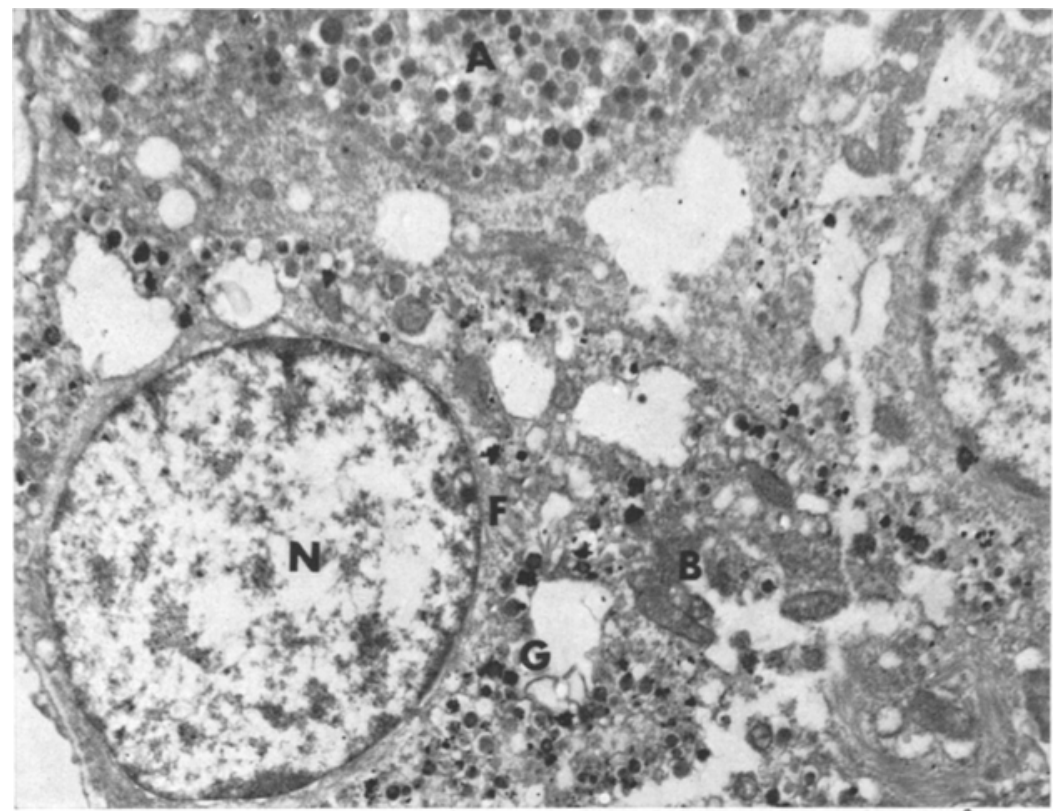

Fig. 4. Low-power electron micrograph of a normal rabbit pancreatic islet after modified sulfide-silver procedure. A cell (A) is present at upper median, other cells are $B$ cell (B). Almost all of the $B$ cell granules contain silver grains, but no A cell granules. Cytoplasm is somewhat destroyed. N : nucleus; G: granule; F : fibrillar substance. $\times 8000$

Fig. 5. Electron micrograph of B cell granules of a normal rabbit pancreatic islet treated by the modified sulfidesilver procedure. Each granule (G) contains droplet-like silver deposits of varying amounts. Sometimes silver droplets show a tendency to form at the periphery of granule cores. $\times 96000$
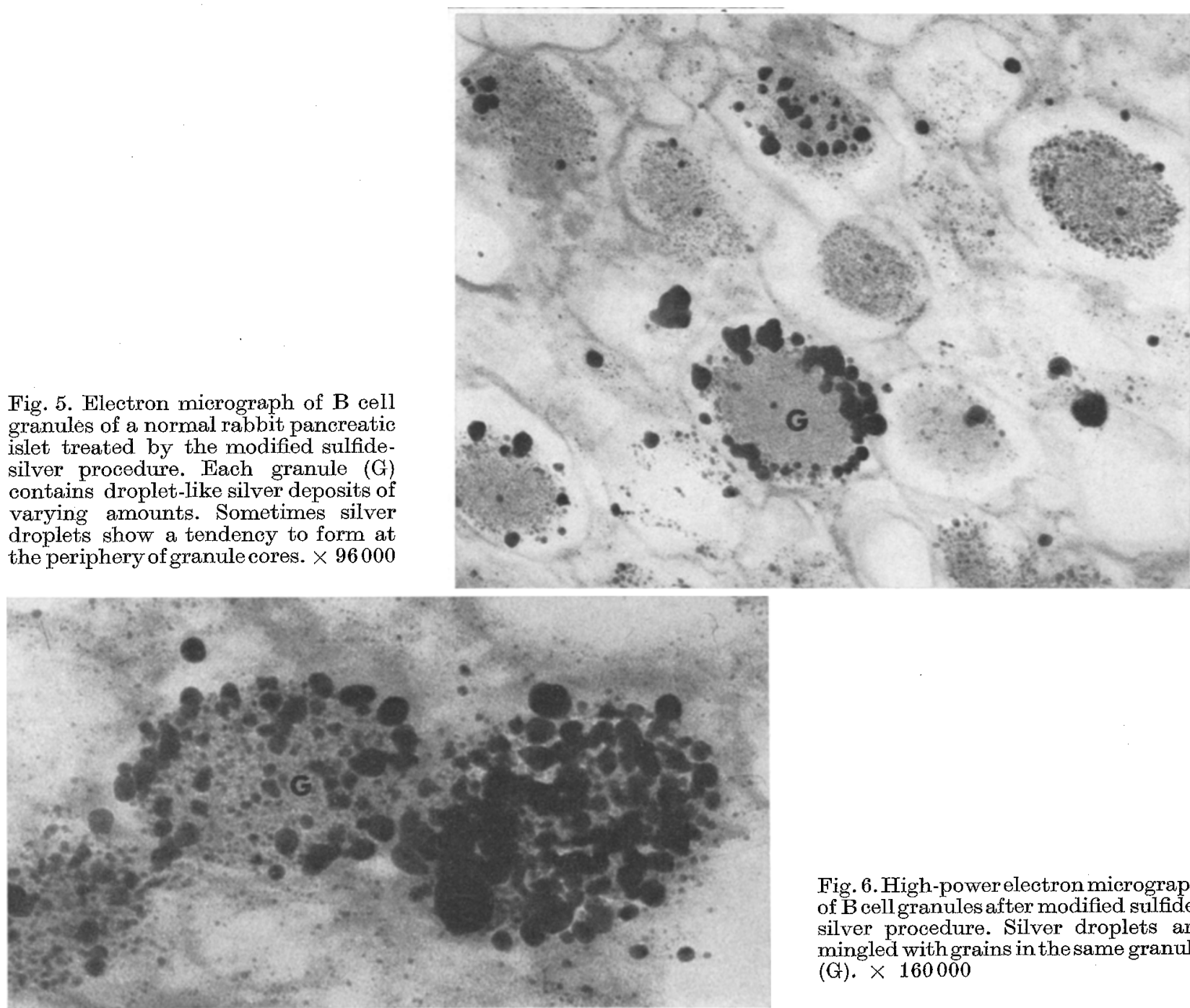

Fig. 6. High-power electron micrograph of B cell granules after modified sulfidesilver procedure. Silver droplets are mingled with grains in the same granule (G). $\times 160000$ 


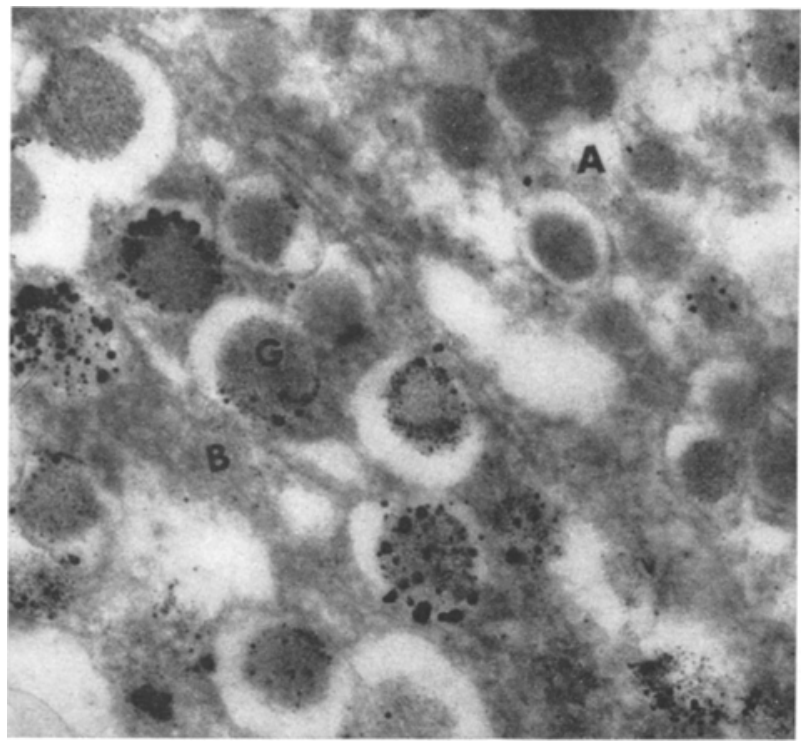

Fig. 7. Electron micrograph of a portion of a normal rabbit pancreatic B cell after modified sulfide-silver procedure. B cell granules (lower left) contain more or less silver deposition, whereas small amounts of deposited silver are observed in some A cell granules (upper right). A : A cell ; B : B cell ; G: granule. $\times 42000$ amounts of heavy metal considered to be zinc have been demonstrated in the cores of secretory granules in the B cells by means of the modified sulfide-silver method for the electron microscope. Some other organelles where zine was weakly positive were the cores of the A cell granules, whereas the other cell components both in A and B cells did not react to this procedure. These findings were thought to support the hypothesis that insulin might be stored in $\mathrm{B}$ cells as granules bound with zinc. The fate of zinc after the release of granules (insulin) from the B cell is not certain from the results of the present experiments. A study of the dynamies of zine in the B cell is now under investigation.

In order to identify the metal demonstrated by the modified sulfide-silver method with zine, it would be necessary to investigate the ${ }^{64} \mathrm{Zn}$ uptake of the $\mathrm{B}$ cell by the method of radioautography. The distribution of the metal in these experiments coincided with the histochemical demonstration of zine by the light microscope, so that the metal detected by the modified sulfide-silver method was considered to be zinc. The modified procedure used in the present experiments. was evolved by OTsuka [1] in order to overcome the disadvantage of damage to cell components using the

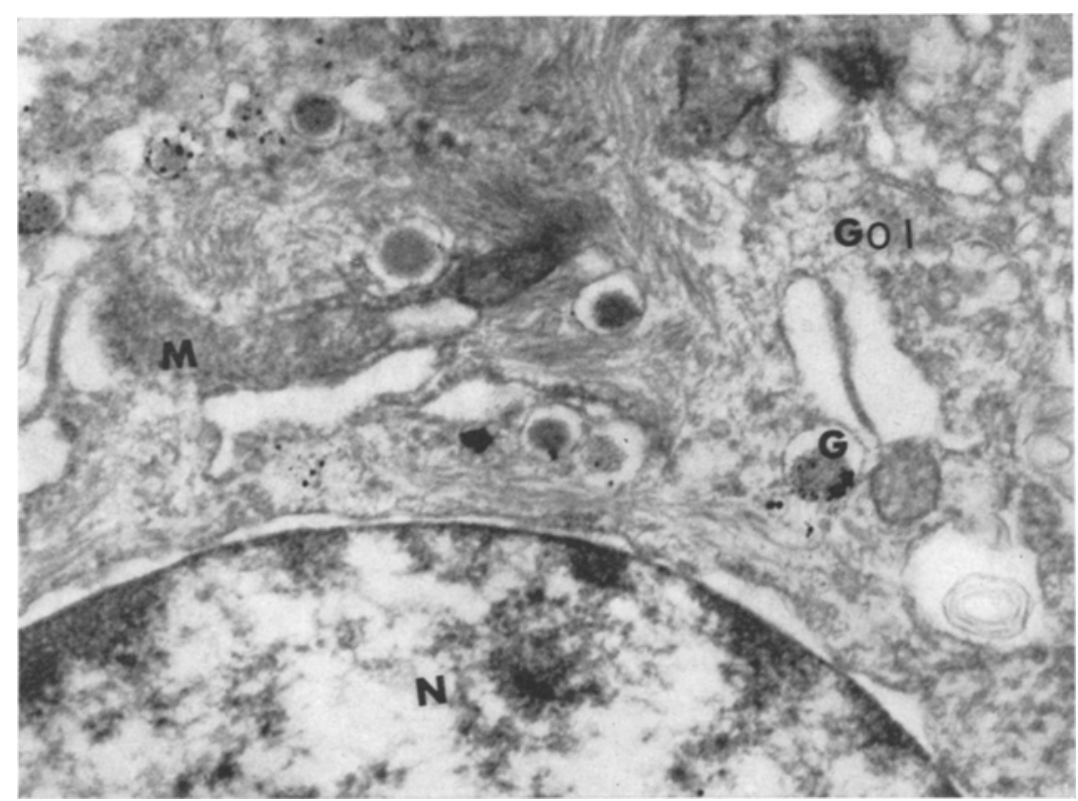

Fig. 8. Electron micrograph of a portion of a normal rabbit pancreatic $\mathbf{B}$ cell after modified sulfide-silver procedure. Mitochondria (M), Golgi area (Gol) and fibrillar substance do not show any positive reaction except for granules. $\mathrm{N}$ : nucleus; $\mathrm{G}$ : granule. $\times 28000$

\section{Discussion}

Almost all the descriptions $[8,13]$ concerning the histochemical detection of zinc in the islet cells from normal rabbits stated that a large amount of zine was found in the B cells, but little or none could be detected in the A cells. In the present experiments, various perfusion with $\mathrm{H}_{2} \mathrm{~S}$-saturated glutaraldehyde fixative. Moreover, this vital fixation could improve the sensitivity of the reaction. Pren and Faskmer [12], in their experiment, fixed the thin sections of the tissue in the $\mathrm{H}_{2} \mathrm{~S}$-saturated glutaraldehyde solution immediately after death, and developed ultra-thin sections in the sulfide-silver developer after embedding in epon. They 
stated that some of the secretory granules of the islet cells gave an almost negative reaction. OKAMoTo and KAWANISHI[10] used $\mathrm{H}_{2} \mathrm{~S}$-saturated $70 \%$ alcohol as a fixative, so that the ultrastructure of cytoplasmic organelles was destroyed and could not be observed except for the secretory granules.

The modified sulfide-silver procedure we have applied to the pancreas preserved fairly adequately the fine ultrastructures of cell components, and was satisfactory for electron microscopic observation.

\section{References}

1. Iвata, Y., and N. Otsuka : Fine structure of synapses in the hyppocampus of the rabbit with special reference to dark presynaptic endings. Z. Zellforsch. 91, $547-553(1968)$.

2. Logothetopotlos, J., J. Kratche, and C.H. Best: Granulation and reactive zinc in the cell of the islets of Langerhans. Effect of prolonged insulin treatment. Diabetes 10, 367-374 (1961).

3. - M. KaneKo, and G.A. Wrenshall: Zine, granulation and extractable insulin of islet cells following hyperglycemia or prolonged treatment with insulin. Brolin, S.E., B. Hellman and H. Knutson, Ed. In the Structure and Metabolism of the Pancreatic Islets. Vol. 3, pp. 333-347. Oxford: Pergamon Press 1964.

4. Mager, M., W.F. MeNary, Jr., and F. Lionetti: Histochemical detection of zine. J. Histochem. Cytochem. 1, 493-504 (1953).

5. MAske, H.: Interaction between insulin and zine in the islets of Langerhans. Diabetes 6, 335-341 (1957).

6. MCNARY, W.F., Jr.: Zine dithizone reaction of panereatic islets. J. Histochem. Cytochem. 2, 185-195 (1954).

7. MuLLonig, G : Further observations on a phosphate buffer for osmium solution in fixation. Fifth Intern. Congr. for Electron Microscopy. S. S. Breese Jr., ed., Vol. 2. p. 8. New York: Academic Press Inc. 1962.
8. Oкайото, K.: Experimental studies on pathogenesis of diabetes mellitus. Folia endocr. jap. 25, 32-61 (1949).

9. - Experimental studies on the pathogenesis of diabetes mellitus; zine theory of diabetes mellitus; preliminary report. Acta Sch. med. Univ. Kioto 27, $43-$ $65(1949)$.

10. - - and H. KaWANISHI : Submicroscopic histochemical demonstration of intercellular reactive zinc in $\beta$ cells of pancreatic islets. Endocr. jap. 13, 305-318 (1966).

11. PIHL, E. : Ultrastructural localization of heavy metals by a modified sulfide-silver method. Histochemie 10, $126-139$ (1967).

12. - , and S. FALKMER: Ultrastructural studies of heavy metals in the islet parenchyma. Diabetologia 2, 215 (1966).

13. StampFu, B.: Das Zink in den Langerhansschen Inseln verschiedener Tierarten. Verh. dtsch. path. Ges. 42, $137(1959)$.

14. Trmm, F.: Zur histochemie der Schwermetalle, Das Sulfid-Silberverfahren. Dtsch. Z. ges. gerichtl. Med. 46, 706-711 (1958).

15. VoxGT, G.E.: Untersuchungen mit der Sulfidsilbermethode an menschlichem und tierischen Bauchspeicheldrüsen (unter besonderer Berücksichtigung des Diabetes mellitus und experimenteller Metallvergiftungen). Virchows Arch. path. Anat. 332, 295-323 (1959).

16. WolfF, H.P., D. Ringleb u. R. Amann: Histochemische Untersuchungen über des Inselzink. Z. ges. exp. Med. 126, 390-416 (1955).

17. YoKoH, S., O. AOZI, K. OKumura, M. FuJII and H. YosHiDA: Study on the formation and release of insulin with special reference to electron microscopic observation. Arch. Histol. Jap. 27, 287-296 (1966).

SADayoshi Yokoh, M.D.

Department of Medicine

Kyoto Prefectural University of Medicine Kyoto, Japan 